\title{
Article \\ Comparison of Soil Properties, Understory Vegetation Species Diversities and Soil Microbial Diversities between Chinese Fir Plantation and Close-to-Natural Forest
}

\author{
Lingyu Hou ${ }^{1,2,3}$, Yongqiang Zhang ${ }^{1,2,3}$, Zhichao $\mathrm{Li}^{1,2,3}$, Guodong Shao ${ }^{4}$, Liguo Song ${ }^{1,2,3}$ and Qiwu Sun ${ }^{1,2,3, *}$ \\ 1 Research Institute of Forestry, Chinese Academy of Forestry, Beijing 100091, China; \\ houlingyu@caf.ac.cn (L.H.); zyq199445@163.com (Y.Z.); urbanelzc@163.com (Z.L.); \\ 17600368768@163.com (L.S.) \\ 2 State Key Laboratory of Tree Genetics and Breeding, State Forestry and Grassland Administration, \\ Beijing 100091, China \\ 3 Key Laboratory of Tree Breeding and Cultivation of State Forestry Administration, \\ Chinese Academy of Forestry, Beijing 100091, China \\ 4 Soil Science of Tropical and Subtropical Ecosystems, Faculty of Forest Sciences and Forest Ecology, \\ University of Goettingen, 37077 Goettingen, Germany; guodongshao@126.com \\ * Correspondence: sqw@caf.ac.cn; Tel.: +86-010-628-89664
}

Citation: Hou, L.; Zhang, Y.; Li, Z.; Shao, G.; Song, L.; Sun, Q. Comparison of Soil Properties, Understory Vegetation Species Diversities and Soil Microbial Diversities between Chinese Fir Plantation and Close-to-Natural Forest. Forests 2021, 12, 632. https://doi.org/10.3390/f12050632

Academic Editor: Marcos

Barrio-Anta, Christian Wehenkel and Carlos A. Lopez-Sanchez

Received: 7 April 2021

Accepted: 11 May 2021

Published: 17 May 2021

Publisher's Note: MDPI stays neutral with regard to jurisdictional claims in published maps and institutional affiliations.

Copyright: (c) 2021 by the authors. Licensee MDPI, Basel, Switzerland. This article is an open access article distributed under the terms and conditions of the Creative Commons Attribution (CC BY) license (https:/ / creativecommons.org/licenses/by/ $4.0 /)$.

\begin{abstract}
With the continuous increase in plantation areas, the reduction of natural forest areas, and the unreasonable management of plantations by human beings, the service function of forest ecosystems has gradually reduced. Therefore, close-to-natural forestry has become important for the sustainable development of modern forestry. However, the differences in soil properties, enzyme activities, microbial diversities, and undergrowth vegetation species diversities have not been systematically explained for Chinese fir (Cunninghamia lanceolata). How do these indicators interact? The purpose of this paper was to study the difference in soil properties and biodiversity in different aged Chinese fir plantations and close-to-natural forests to explore their interactions and to provide direction for close-to-nature management. The results showed that the above indicators were significantly different in different aged Chinese fir plantations, soil $\mathrm{pH}$, organic matter, total nitrogen, total phosphorus, total potassium, alkali-hydrolyzed nitrogen, available phosphorus concentrations, and urease activities in close-to-natural forests were significantly higher than plantations. It is worth mentioning that the richness of undergrowth vegetation species diversity (especially shrubs) and soil microbial diversities (especially fungi) in the close-to-natural forests were obviously higher than those in plantations. The correlation analysis results showed that the diversity of shrub species with respect to soil properties presented a higher correlation than herb species, the diversity of fungi with respect to soil properties presented a higher correlation than that observed for bacteria, and the diversity of fungi were significantly correlated with the diversity of undergrowth vegetation species diversities, but the correlation between bacteria and undergrowth vegetation species diversities was not significant. Our results suggest that the above factors are fundamental factors for the transformation of Chinese fir plantations to close-to-natural forests. To realize close-to-natural forestry, we must change the tree structure, combine the difference of those factors in different aged plantations, restore undergrowth vegetation species diversity, and thus improve microbial diversity and increase decomposition, transformation, and improvement of soil properties.
\end{abstract}

Keywords: Chinese fir plantation; close-to-natural forest; species diversity; soil fungi and bacteria; shrubs and herbs; forest management; temporal evolution

\section{Introduction}

As the main part of terrestrial ecosystems, forest resources are the most complete and powerful natural resource pool, gene pool, and reservoir [1-3]. They have important and no-substitutive functions in water conservation, conserving soil and water, regulating 
the climate, improving the environment, and the conservation of biological diversity [4]. Compared with the direct economic benefits of forest resources, their ecological benefits are much higher. For a long time, in order to change the situation of the sharp decrease in natural forests and improve the environment, we carried out a wide range of afforestation campaigns in China such as the project of returning the grain plots to forestry, the project of protecting natural forests, and the project of combating desertification [5]. As we all know, compared with natural forests, plantations have many disadvantages as follows: (a) plantations have poor soil and water conservation due to the loss of stabilizing natural vegetation (Sun et al., 2018); (b) nutrient cycles in plantations are interrupted, and soil nutrients are increasingly deficient [6]; (c) the ecological conditions of plantations are very weak [7]; and (d) the allelopathy and self-toxicity of plantations are more serious than in natural forests [8]. Furthermore, plantations with simple structures, single species, and high density are even called "green deserts". However, the development of close-to-natural forestry provides a basis for the sustainable development of plantations because such plantation typology can result in long-term stability and greater ecological value.

Chinese fir (Cunninghamia lanceolata) is the main timber species in southern China, and the Eighth National Forest Resources Inventory results of China showed that the area of plantations in general reached 69.33 million hectares, accounting for $36 \%$ of the forest area, among which the area of Chinese fir plantations reached 10.96 million hectares, accounting for $15.8 \%$ of China's plantation area [9]. Unfortunately, the natural Chinese fir forests were converted into plantations with a simple community structure and single species after logging, controlled burning, and soil preparation [10-12]. In recent years, many domestic and international scholars have conducted extensive research on close-tonatural forests $[13,14]$. The investigation found that natural Chinese fir forests had basically disappeared due to conversion. With respect to the problems of the management of Chinese fir plantations, many researchers have proposed that the sustainable development of Chinese fir should move toward close-to-nature silviculture. The most fundamental purpose was to achieve the closest state to nature through reasonable management to restore its original ecological value [15-17]. Today, the close-to-nature management of Chinese fir is practiced ceaselessly, and the introduction of indigenous broad-leaved species into Chinese fir forests has also been achieved [18-20]. To better guide the close-to-nature development of Chinese fir plantations, it is of great significance to explore the fundamental factors of the development of close-to-natural forestry such as soil properties, soil enzyme activities, soil microbial diversities, and the change in undergrowth vegetation diversities.

Natural forests achieve a more stable forest structure because of their long-term natural renewal and succession, and the close-to-natural forest enables the stand to conduct spontaneous production close to natural ecology [21-23], so as to achieve a dynamic balance of the forest biological community, recover the natural species with artificial assistance, and maximize the maintenance of the diversity of forest biological species, the largest biological gene pool on Earth [24]. Soil properties, undergrowth vegetation, and soil microbes influence each other and interact with each other $[25,26]$. Vegetation absorbs nutrient transformed by microbes from the soil and returns them to the soil in the form of litter and root secretion in the life process, affecting the soil properties. In addition, soil properties affect the decomposition and transformation of microbes and thereby affect the growth of plants. We must make clear the difference in the environments and their interplay in different aged Chinese fir plantations if we want to realize close-to-natural forestry. Therefore, in this paper, we studied the differences in soil properties, enzyme activities, plant diversities, and microbial diversities in different aged plantations. Starting from the environment in forests, we provide suggestions for the close-to-natural development of plantations. 


\section{Materials and Methods}

\subsection{Site Selection and Soil Sampling}

The study area was located in Fenyi County, Jiangxi Province, China, at the Experimental Center of Subtropical Forest, Chinese Academy of Forestry. It has a subtropical climate; the annual average temperature is $17.2^{\circ} \mathrm{C}$, annual average rainfall is $1600 \mathrm{~mm}$, and the annual average frost-free period is 270 days. The soil type was Rhodic and Xanthic. All plots were located on the Rhodic. Soil samples were taken from Chinese fir plantations at six different sites: young forest (6 years old; YF), immature forest (15 years old; IMMF), near-mature forest (25 years old; NMF), mature forest (32 years old; MF), over-mature forest (50 years old; OMF), and close-to-natural forest (average age was 50 years old; $\mathrm{CNF}$ ) in late October 2018 (Table 1). All plantations were second-generation Chinese fir forests, managers controlled burning before planting on the cutting land, after soil preparation and planting, and trees were tended (weeding and fertilizer) in the first three years, so all plantations had the same baseline site information. The first five plantations were intermediate cut at eight (besides YF) and 18 (besides YF, IMF) years old, then, managers just cut seedlings of other species than Chinese fir every three year, today, the plantations have more than $95 \%$ Chinese fir. CNF is an uneven-aged forest; more than 10 decades ago, the Chinese fir began to germinate naturally and was associated with broad-leaf species. Originally, managers tended Chinese fir, but then artificial interference was terminated; now, CNF has about $65 \%$ Chinese fir, the oldest about 120 years old, with a diameter of about $63.8 \mathrm{~cm}$ (24 October 2018) —we called this a "close-to-nature forest" or "objective forest", which is close to the natural forest in terms of stand structure.

Table 1. Basic condition of plots of Chinese fir plantations at different ages: YF (young forest, six years old), IMF (immature forest, 15 years old), NMF (near-mature forest, 25 years old), MF (mature forest, 32 years old), OMF (over-mature forest, 50 years old), CNF (close-to-natural forest, average age was 50 years old); all forests were tended (weeding and fertilizer) in the first three years, all forests except for YF underwent intermediate cutting at eight years old, all forests beside YF and NMF underwent intermediate cutting at 18 years. CNF indicates an uneven-aged forest; the oldest Chinese fir was about 120 years old with a diameter of about $63.8 \mathrm{~cm}$ (24 October 2018). The mean and standard deviation were calculated from three stands with the same age; DBH is the diameter at breast height.

\begin{tabular}{cccccc}
\hline Stand Age & Age (a) & Slope Aspect & $\begin{array}{c}\text { Slope } \\
\text { Gradient }\left({ }^{\circ}\right)\end{array}$ & $\begin{array}{c}\text { Mean Tree } \\
\text { Height }(\mathbf{m})\end{array}$ & $\begin{array}{c}\text { Mean DBH } \\
\text { (cm) }\end{array}$ \\
\hline YF & 6 & Southeast & $25 \sim 28$ & $7.37 \pm 0.55$ & $7.11 \pm 0.12$ \\
IMF & 15 & South & $25 \sim 28$ & $12.40 \pm 1.12$ & $11.46 \pm 0.35$ \\
NMF & 25 & South & $23 \sim 25$ & $15.49 \pm 1.56$ & $21.37 \pm 2.15$ \\
MF & 32 & South & $24 \sim 27$ & $17.22 \pm 1.79$ & $19.03 \pm 1.79$ \\
OMF & 50 & South & $20 \sim 23$ & $19.02 \pm 1.74$ & $20.90 \pm 1.49$ \\
CNF & - & Southeast & $22 \sim 25$ & $25.26 \pm 2.46$ & $32.15 \pm 2.15$ \\
\hline
\end{tabular}

We divided the forest map into six stand aged blocks; each block had three plots of $400 \mathrm{~m}^{2}(20 \mathrm{~m} \times 20 \mathrm{~m})$. Soils were sampled at two depths $(0-20 \mathrm{~cm}$ and $20-40 \mathrm{~cm})$, except the organic forest floor. Five soil samples were collected from four corners and a central point, mixed thoroughly, and then divided into two parts and placed into soil bags. One soil sample for analyses was immediately stored at $4{ }^{\circ} \mathrm{C}$; after being transported to the laboratory, soil samples were stored at $-80{ }^{\circ} \mathrm{C}$ prior to microbial community analysis and other soil samples were air dried, ground, and sieved $(0.149 \mathrm{~mm}$ and $2 \mathrm{~mm})$ to analyze the chemical properties.

\subsection{Plant Investigation}

In every plot, five $5 \mathrm{~m} \times 5 \mathrm{~m}$ (four corners and one central) little sample plots were selected to investigate the shrub layer according to the diagonal method. Small trees with a diameter less than $5 \mathrm{~cm}$ in the sample plots were recorded as shrubs. At the same time, five 
small sample plots of $2 \mathrm{~m} \times 2 \mathrm{~m}$ (four corners and one central) were selected to investigate the herb layer. In each plot, the species name, number of plants/clusters, height, and coverage of each plant were recorded. Five indexes were used to calculate the shrub and grass diversity under the Chinese fir forest (Gao et al., 2016):

1. Richness index: $R=S, D_{m}=(S-1) / \ln N$;

2. Diversity index: $D_{S}=1-\sum P i^{2}, H=-\sum P i \ln P i$;

3. Evenness index: $J_{s i}=\left(1-\sum P i^{2}\right) /(1-1 / S), J_{s w}=\left(-\sum P i \ln P i\right) / \ln S$.

where $S$ is the total number of species in the community; $N$ is the total number of individuals of all species; $P i$ is the proportion of $i$ in all species; $D_{m}$ is the Margalef index; $D_{S}$ is the Simpson index; $H$ is the Shannon index; $J_{s i}$ is the McIntosh evenness index; and $J_{s w}$ is the Shannon evenness index.

\subsection{Soil Properties}

Soil physical properties were investigated using the cutting ring method [27], and the soil water content in the $105^{\circ} \mathrm{C}$ oven was dried to constant weight. Soil pH was measured using a suspension of air-dried soil and distilled water (in a ratio of 1:5). Soil organic matter (SOM) was determined by the $\mathrm{K}_{2} \mathrm{Cr}_{2} \mathrm{O}_{7}-\mathrm{H}_{2} \mathrm{SO}_{4}$ oxidation method (Lefroy et al., 1993). Soil total nitrogen (TN) was measured using a 2300 Kjeltec Portern Analyzer Unit [28]. Determination of nitrogen availability by the diffusion method was also performed. Soil total phosphorus (STP) and soil total potassium (STK) were extracted according to previously described literature (Rosenstock et al., 2016). Available phosphorus (AP) and available potassium (AK) were extracted and assayed according to previously described literature [29]. STP, STK, AP, and AK concentrations were measured by inductively coupled plasma emission spectrometry (Spectro Analytical Instruments, Spectro Arcos ICP, Kleve, Germany) [30,31]. Each treatment consisted of three replicates, with nine soil samples per replicate.

\subsection{Soil Enzyme Activities Analyses}

Soil enzymes catalyze the conversion of complex organic substances into simple inorganic compounds for plant use [32]. Polyphenol oxidase plays an important catalysis in the process of soil humus, urease can convert urea into ammonia in the soil, cellulase plays an important catalysis in soil carbon metabolism, and acid phosphatase can accelerate the dephosphorization of organophosphorus and improve the efficiency of phosphorus in soil [33].

Activities of the soil polyphenol oxidase, urease, cellulase, and acid phosphatase were determined by spectrophotometry (Qingdao Jisskang Biotechnology Co. Ltd.Qingdao, China). Briefly, using air dried, ground prior, and sieved $(0.149 \mathrm{~mm})$ soil samples of $0.05 \mathrm{~g}$, $0.25 \mathrm{~g}, 0.1 \mathrm{~g}$, and $0.1 \mathrm{~g}$, respectively, adding the appropriate reagent to the water bath culture at a certain temperature following the instructions. Fluorescence at $450 \mathrm{~nm}$ was determined on a SpectraMax Paradigm Multi-Mode detection platform (Molecular devices, San Jose, CA, USA).

\subsection{Soil Microbial Communities Analyses}

First of all, a Biolog-ECO microplate (Biolog ECO plate ${ }^{\mathrm{TM}}$ ) (Biolog Inc., Hayward, CA, USA) with 31 carbon substrates was used to analyze the metabolic characteristics of the soil microbial communities. The inoculation solution for the microplate was prepared according to Classen et al. (2010). The value of the wavelength at $590 \mathrm{~nm}$ (color + turbidity) and $750 \mathrm{~nm}$ (turbidity) was read on a MicroLog ${ }^{\mathrm{TM}}$ microplate reader (version 4.20.05; Biolog Inc., Hayward, CA, USA) at 24 h, 48 h, 72 h, 96 h, 120 h, 144 h, and 168 h. Microbial community metabolic activity was expressed as the value at $590 \mathrm{~nm}$ minus the value at $750 \mathrm{~nm}$ to calculate the average well color development (AWCD).

Then, to reveal which microbial species were present in the soil, Miseq high-throughput sequencing was performed at Majorbio Co. (Shanghai, China). Sequencing experiments demanded DNA extraction, PCR amplification, and product purification, real- 
time quantitative PCR, Miseq library construction, and Miseq sequencing. TransStart FastPfu DNA Polymerase (AP221-02, TransGen) was used for PCR amplification, and amplification was carried out on an ABI GeneAmp ${ }^{\circledR}$ 9700. ITS1-forward primer $\left(5^{\prime}\right.$ GGAAGTAAAAGTCGTAACAAGG-3') and ITS2-reverse primer (5'-ATCCTCCGCTTATTG ATATGC- $3^{\prime}$ ) were used for amplifying the fungal DNA fragment, while 338-forward primer (5'-GTACTCCTACGGGAGGCAGCA-3') and 806-reverse primer (5'-GTGGACTACHVGGG TWTCTAAT- $3^{\prime}$ ) were used for amplifying bacterial DNA fragment (Aanderud et al., 2013).

\subsection{Statistical Analyses}

An analysis of variance (ANOVA) and correlation analysis (Person, $\alpha=0.05$ ) were conducted using R i386 3.3.1 (R Core Team, 2015). $R$ was used to evaluate the differences in the soil chemical properties, enzyme activities and abundance, diversity, and composition of microbial and plant communities between different stand ages of Chinese fir forest (Tukey's HSD test, $\alpha=0.05$ ).

\section{Results}

\subsection{General Soil Properties}

Soil physical properties of Chinese fir close-to-natural forests were similar with those of plantations with different stand ages. The soil bulk densities, saturated moisture, capillary capacity, field capacity, total porosity, and capillary porosity in the close-to-natural forest were at a medium level; soil moisture of CNF was higher than of IMMF, NMF, and MF plantation (Table 2).

Table 2. General soil physical properties at the Experimental Center of Tropical Forest, China. Properties were average values measured in soil samples taken from each replicate plot in $2018(n=9)$. $p$-values within each column were determined by ANOVA. Different lowercase letters between different stand ages in the same soil layer indicated significant differences as determined by Tukey's HSD test $(\alpha=0.05)$. The same below.

\begin{tabular}{|c|c|c|c|c|c|c|c|c|}
\hline $\begin{array}{l}\text { Stand } \\
\text { Age }\end{array}$ & $\begin{array}{c}\text { Soil } \\
\text { Layer } \\
(\mathrm{cm})\end{array}$ & $\begin{array}{c}\text { Soil Bulk } \\
\text { Density } \\
\left(\mathrm{g} \cdot \mathrm{cm}^{-3}\right)\end{array}$ & $\begin{array}{c}\text { Soil } \\
\text { Moisture (\%) }\end{array}$ & $\begin{array}{l}\text { Saturated } \\
\text { Moisture } \\
\left(\mathrm{t} \cdot \mathrm{hm}^{-2}\right)\end{array}$ & $\begin{array}{c}\text { Capillary } \\
\text { Capacity }\left(\mathbf{t} \cdot \mathbf{h m}^{-2}\right)\end{array}$ & $\begin{array}{c}\text { Field } \\
\text { Capacity }\left(\mathrm{t} \cdot \mathrm{hm}^{-2}\right)\end{array}$ & $\begin{array}{c}\text { Total } \\
\text { Porosity (\%) }\end{array}$ & $\begin{array}{c}\text { Capillary } \\
\text { Porosity (\%) }\end{array}$ \\
\hline YF & $0 \sim 20$ & $1.17 \pm 0.02 b$ & $28.71 \pm 0.10 \mathrm{a}$ & $459.23 \pm 19.69 b$ & $377.01 \pm 19.69 a$ & $302.36 \pm 16.31 a$ & $54.68 \pm 3.46 \mathrm{ab}$ & $44.88 \pm 3.16 a$ \\
\hline (6 years) & $20 \sim 40$ & $1.19 \pm 0.02 \mathrm{a}$ & $28.58 \pm 0.54 a$ & $479.17 \pm 25.26 a$ & $371.37 \pm 15.26 a$ & $326.95 \pm 14.26 a$ & $54.80 \pm 4.66 a$ & $42.57 \pm 2.67 \mathrm{~b}$ \\
\hline IMF & $0 \sim 20$ & $1.21 \pm 0.02 \mathrm{a}$ & $24.19 \pm 1.55 c$ & $404.84 \pm 15.51 c$ & $311.50 \pm 15.51 \mathrm{c}$ & $256.23 \pm 11.26 c$ & $48.67 \pm 4.94 c$ & $37.79 \pm 2.65 \mathrm{~d}$ \\
\hline (15 years) & $20 \sim 40$ & $1.25 \pm 0.00 \mathrm{~b}$ & $26.47 \pm 0.26 b$ & $406.20 \pm 14.24 \mathrm{c}$ & $350.94 \pm 14.24 b$ & $283.51 \pm 13.64 c$ & $52.63 \pm 5.15 b$ & $45.54 \pm 2.93 a$ \\
\hline NMF & $0 \sim 20$ & $1.21 \pm 0.01 \mathrm{a}$ & $26.76 \pm 1.34 b$ & $491.65 \pm 15.88 \mathrm{a}$ & $334.13 \pm 15.88 b$ & $263.72 \pm 9.81 b c$ & $56.07 \pm 3.24 a$ & $38.11 \pm 2.46 \mathrm{~d}$ \\
\hline (25 years) & $20 \sim 40$ & $1.26 \pm 0.01 b$ & $21.95 \pm 1.14 \mathrm{~d}$ & $468.73 \pm 15.16 a$ & $347.99 \pm 25.16 b$ & $294.84 \pm 16.64 b$ & $54.09 \pm 4.95 a$ & $40.08 \pm 3.16 c$ \\
\hline MF & $0 \sim 20$ & $1.18 \pm 0.01 b$ & $24.36 \pm 1.42 c$ & $414.70 \pm 18.59 c$ & $324.18 \pm 18.59 b c$ & $270.83 \pm 12.61 b$ & $53.23 \pm 2.64 b$ & $41.91 \pm 2.59 c$ \\
\hline (32 years) & $20 \sim 40$ & $1.22 \pm 0.01 \mathrm{a}$ & $24.92 \pm 0.33 c$ & $414.50 \pm 16.25 b c$ & $330.04 \pm 16.25 c$ & $277.97 \pm 16.16 c$ & $52.40 \pm 2.94 b$ & $41.87 \pm 3.16 b$ \\
\hline OMF & $0 \sim 20$ & $1.21 \pm 0.01 \mathrm{a}$ & $29.39 \pm 0.91 a$ & $427.88 \pm 19.62 c$ & $342.55 \pm 19.62 b$ & $288.97 \pm 12.26 b$ & $53.67 \pm 3.96 b$ & $43.33 \pm 3.49 b$ \\
\hline (50 years) & $20 \sim 40$ & $1.22 \pm 0.0 \mathrm{a}$ & $19.56 \pm 1.58 \mathrm{~d}$ & $370.39 \pm 15.25 \mathrm{~d}$ & $309.55 \pm 15.25 \mathrm{~d}$ & $257.28 \pm 16.15 \mathrm{~d}$ & $50.27 \pm 4.64 c$ & $41.98 \pm 3.46 b$ \\
\hline \multirow[b]{2}{*}{$\mathrm{CNF}$} & $0 \sim 20$ & $1.21 \pm 0.00 \mathrm{a}$ & $27.24 \pm 1.23 \mathrm{ab}$ & $423.07 \pm 16.66 c$ & $322.80 \pm 13.65 b c$ & $257.51 \pm 13.46 c$ & $49.19 \pm 3.84 \mathrm{c}$ & $37.52 \pm 2.76 \mathrm{~d}$ \\
\hline & $20 \sim 40$ & $1.22 \pm 0.01 a$ & $28.43 \pm 1.64 a$ & $437.25 \pm 14.59 \mathrm{~b}$ & $377.57 \pm 16.59 a$ & $303.93 \pm 15.69 a$ & $52.96 \pm 2.49 a b$ & $45.73 \pm 3.65 a$ \\
\hline
\end{tabular}

Overall, soil nutrients were significantly different between different aged Chinese fir plantations and were significantly different among different depths (Tukey's HSD test, $p<0.05$, Figure 1). The $\mathrm{pH}, \mathrm{SOM}, \mathrm{STN}$, and STP concentrations of CNF were significantly higher than the values in other plantations (ANOVA; $p<0.05$, Figure $1 \mathrm{~A}-\mathrm{D}$ ), while the STK concentration was not significantly different except for IMMF (ANOVA; $p<0.05$, Figure 1E). Moreover, the SAN and SAP concentrations of CNF were significantly higher than NMF, MF, OMF and MF, and OMF, respectively (ANOVA; $p<0.05$, Figure 1F,G), but were not significantly different from YF, IMMF and YF, IMMF, and NMF, respectively (ANOVA; $p<0.05$, Figure $1 \mathrm{~F}, \mathrm{G})$. The SAK concentration of CNF was significantly higher than that of NMF, MF, and OMF, but significantly lower than that of YF and IMMF (ANOVA; $p<0.05$, Figure $1 \mathrm{H})$. Finally, the indicators except STK in the upper soil layer presented a significantly higher value than in the lower soil layer $(p<0.05$, Figure 1$)$. Above all, soil properties were significantly different in different aged Chinese fir plantations, and with the increase in forest age, after MF, the soil $\mathrm{pH}, \mathrm{SOM}$, STP, STK, SAN, SAP, and SAK concentrations gradually increased, but the soil properties of all plantations were significantly lower than CNF. 

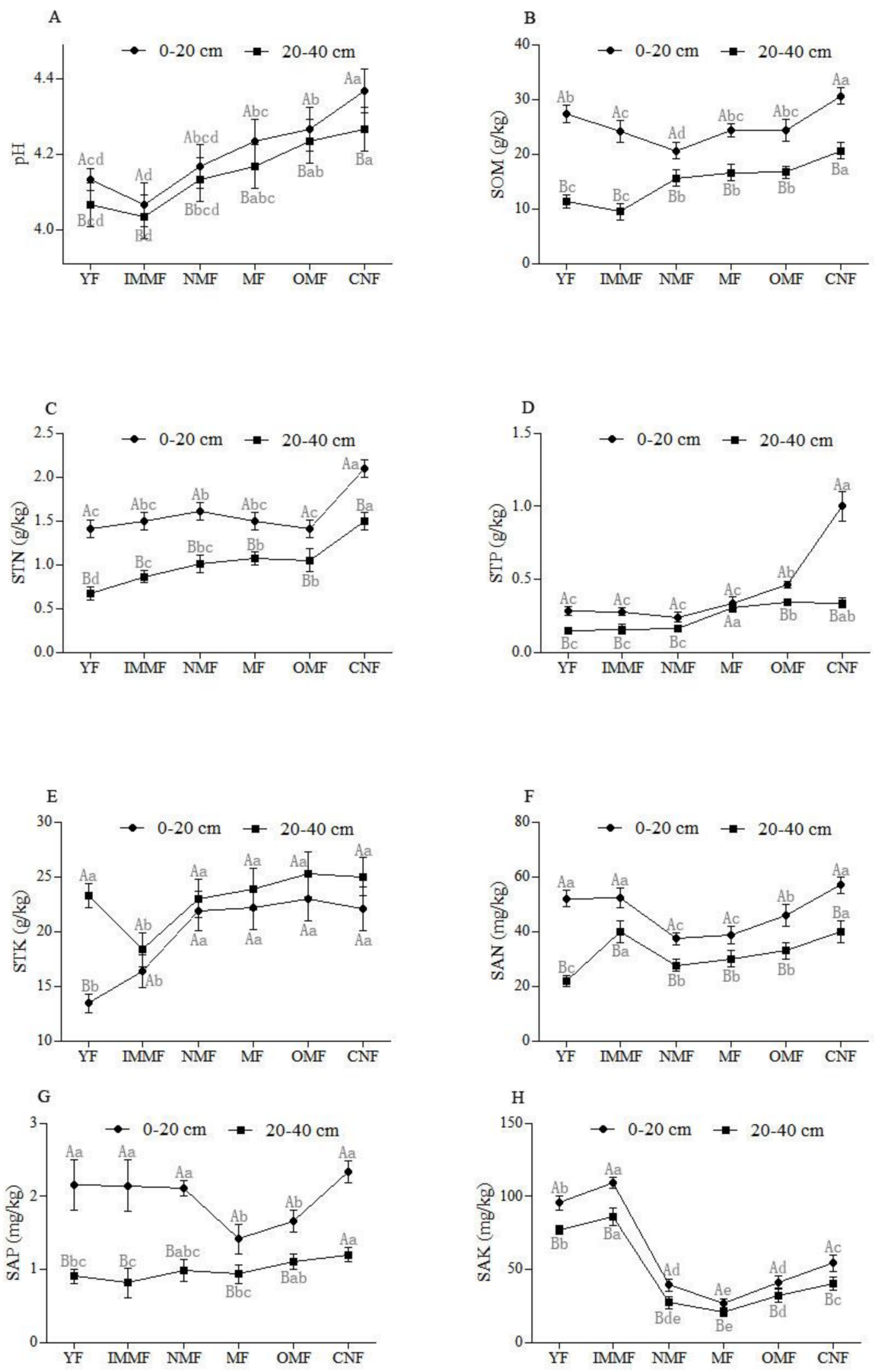

Figure 1. Soil chemical characteristics. General soil properties at the Experimental Center of Subtropical Forest, China. Properties are average values measured for soil samples (the experiment was repeated three times for each sample) taken from each replicate plot in $2018(n=9)$. $p$-values within each column were determined by ANOVA. Different lowercase letters and different uppercase letters represent significant differences between the same soil depth of different stand ages and between different soil depths $(0-20 \mathrm{~cm}$ and $20-40 \mathrm{~cm})$ of the same stand age $(p<0.05)$, respectively, as determined by Tukey's HSD test $(\alpha=0.05)$. The same below. (A) $\mathrm{pH}$ values, (B) soil organic matter (SOM) concentrations, $($ C) soil total nitrogen (STN) concentrations, (D) soil total phosphorus (STP) concentrations, (E) soil total potassium (STK) concentrations, (F) soil alkali-hydrolyzable nitrogen (SAN) concentrations, $(\mathbf{G})$ soil available phosphorus (AP) concentrations, $(\mathbf{H})$ soil available potassium (SAK) concentrations in different stand ages and different soil depths. 


\subsection{Soil Enzyme Activity}

The analyses of soil enzyme activities are helpful to understand the bioconversion process, trends of soil carbon, nitrogen, and phosphorus, and the efficiency of soil potential fertility. In this paper, polyphenol oxidase activity was low in YF and IMMF, but significantly higher in NMF, then decreased until OMF. Urease in the soil of CNF presented significantly higher activities than in other plantations $(p<0.05$; Figure 2B). The activities of cellulase and acid phosphatase first decreased, then increased, and finally decreased with the increase in stand age. The results showed that soil enzyme activities in different stand ages were significantly different $(p<0.05)$, and the trend of those four soil enzymes at the same stand ages were different (Figure 2).
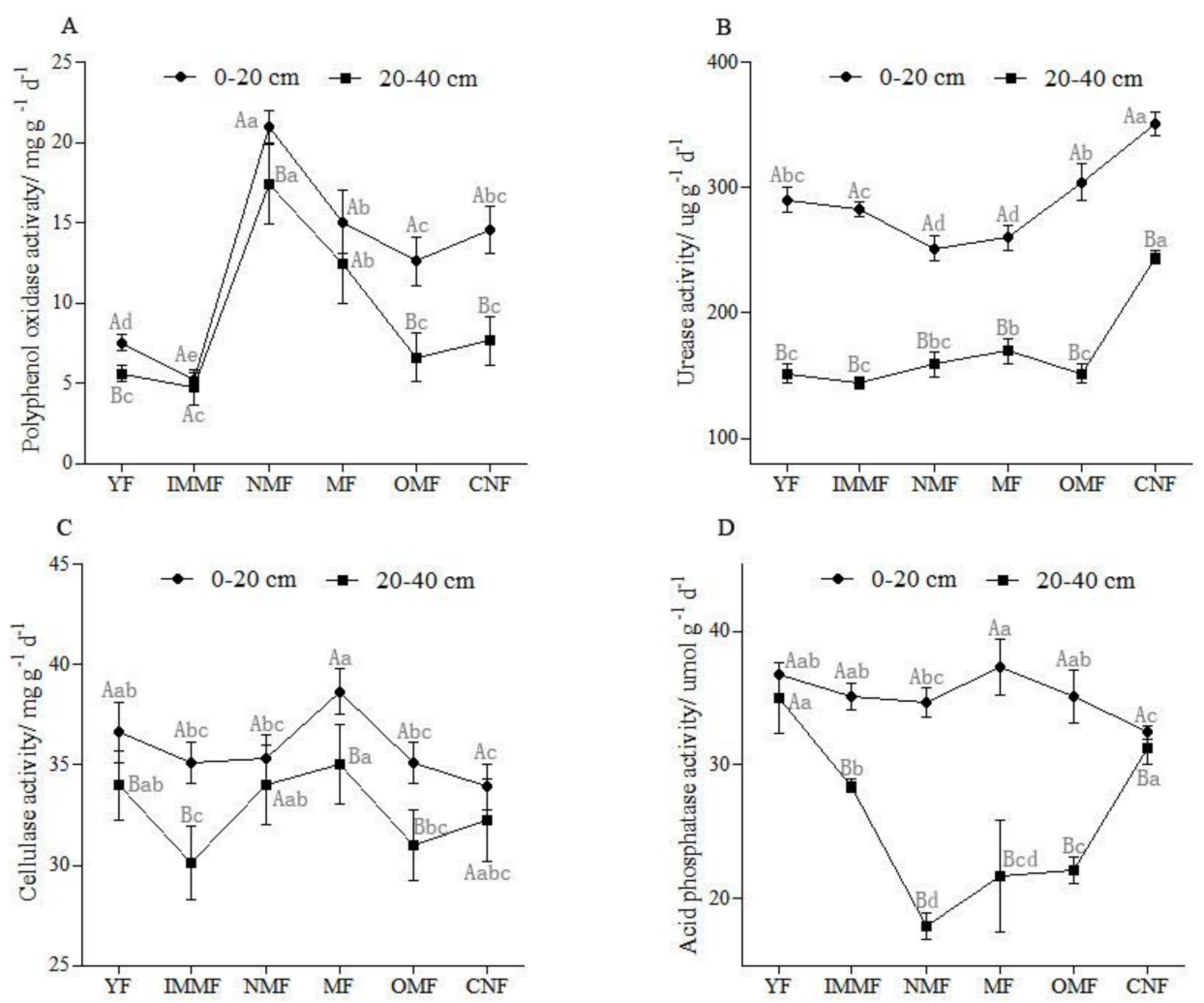

Figure 2. Soil enzyme activities at different stand ages. Different lowercase letters and different uppercase letters represent significant differences between the same soil depth of different stand ages and between different soil depths of the same stand ages $(p<0.05)$, respectively. (A) polyphenol oxidase activity, (B) urease activity, (C) cellulase activity, and (D) acid phosphatase activity.

\subsection{Management Effects on Plant Diversity}

Survey results of undergrowth vegetation species diversity showed a total of 134 species in 108 genera and 65 families including 100 species of 76 genera in 44 families of shrubs and 34 species of 32 genera in 26 families of herbs. First, the undergrowth vegetation species in Chinese fir CNF comprised 66 species of 58 genera in 38 families including 53 species of 48 genera in 29 families of shrubs, and 13 species of 12 genera in 12 families of herbs (Table 3), higher than in other plantations. The undergrowth vegetation species number of MF was higher than in OMF. In addition, the survey results showed that species in the plantations were all found in the CNF, while $31.82 \%$ of shrubs and grass species in the CNF were not found in the plantations. In this investigation, we found that the YF, IMMF, and NMF were dominated by ferns, and the ferns were distributed in patches, while the MF, $\mathrm{OMF}$, and CNF were characterized by a few and small ferns with a scattered distribution. 
Table 3. Plant diversity survey under different stand ages of Chinese fir forest. Species, genes, and family mean plant species presented for the same stand ages belong to different taxa. Dominant undergrowth vegetation species were ranked by species importance values for the same stand ages.

\begin{tabular}{|c|c|c|}
\hline Stand Age & Species, Genes and Family & Dominant Undergrowth Vegetation Species \\
\hline $\begin{array}{c}\text { YF } \\
\text { (6 years) }\end{array}$ & 38,33 , and 26 & $\begin{array}{c}\text { Rubus buergeri, Maesa acuminatissima, Paederia scandens, Dryopteris fuscipes, } \\
\text { Centotheca lappacea, Lygodiaceae }\end{array}$ \\
\hline $\begin{array}{l}\text { IMF } \\
\text { (15 years) }\end{array}$ & 24,23, and 19 & $\begin{array}{c}\text { Uncaria rhynchophylla, Machilus velutina, Smilax glabra, Diplazium donianum, } \\
\text { Dryopteris fuscipes, Cyclosorus dentatus }\end{array}$ \\
\hline $\begin{array}{l}\text { NMF } \\
\text { (25 years) }\end{array}$ & 40,37 , and 31 & $\begin{array}{c}\text { Maesa acuminatissima, Machilus pauhoi, Machilus velutina, Ilex pubescens, } \\
\text { Dryopteris fuscipes, Diplazium donianum, Woodwardia japonica }\end{array}$ \\
\hline $\begin{array}{l}\text { MF } \\
\text { (32 years) }\end{array}$ & 58,51 , and 35 & $\begin{array}{c}\text { Maesa acuminatissima, Machilus velutina, Rubus rosaefolius, Diplazium donianum, } \\
\text { Arthraxon hispidus, Dicranopteris linearis }\end{array}$ \\
\hline $\begin{array}{l}\text { OMF } \\
\text { (50 years) }\end{array}$ & 51,45 , and 31 & $\begin{array}{c}\text { Maesa acuminatissima, Machilus pauhoi, Ilex pubescens, Diplazium donianum, } \\
\text { Adiantum flabellulatum, Lindsaea orbiculata }\end{array}$ \\
\hline $\mathrm{CNF}$ & 66,58 , and 38 & $\begin{array}{c}\text { Maesa acuminatissima, Oreocnide frutescens, Piper hancei, Ficus sarmentosa, } \\
\text { Trachelospermum jasminoides, Diplazium donianum, Ophiorrhiza chinensis, Cyperus } \\
\text { rotundus, Viola verecunda }\end{array}$ \\
\hline
\end{tabular}

Undergrowth vegetation species diversities were expressed by richness, diversity, and evenness indices. First, the richness index of shrubs and herbs was higher in the YF than in the IMMF and increased significantly from the IMMF to CNF $(p<0.05)$, but decreased after the MF, and was then significantly lower than that of the CNF (ANOVA, $p<0.05$; Figure $3 \mathrm{~A}$ ). Moreover, the diversity index of shrubs and herbs in plantations decreased from the YF to IMMF $(p<0.05)$, but increased from the IMMF to MF $(p<0.05)$, and decreased after maturity $(p<0.05)$. Finally, the CNF presented a significantly higher Shannon index and Simpson index than other plantations, especially for shrubs (ANOVA, $p<0.05$; Figure 3B). The CNF presented a significantly higher Shannon evenness index and McIntosh evenness index than other plantations, especially compared with the OMF (ANOVA, $p<0.05$; Figure 3C).
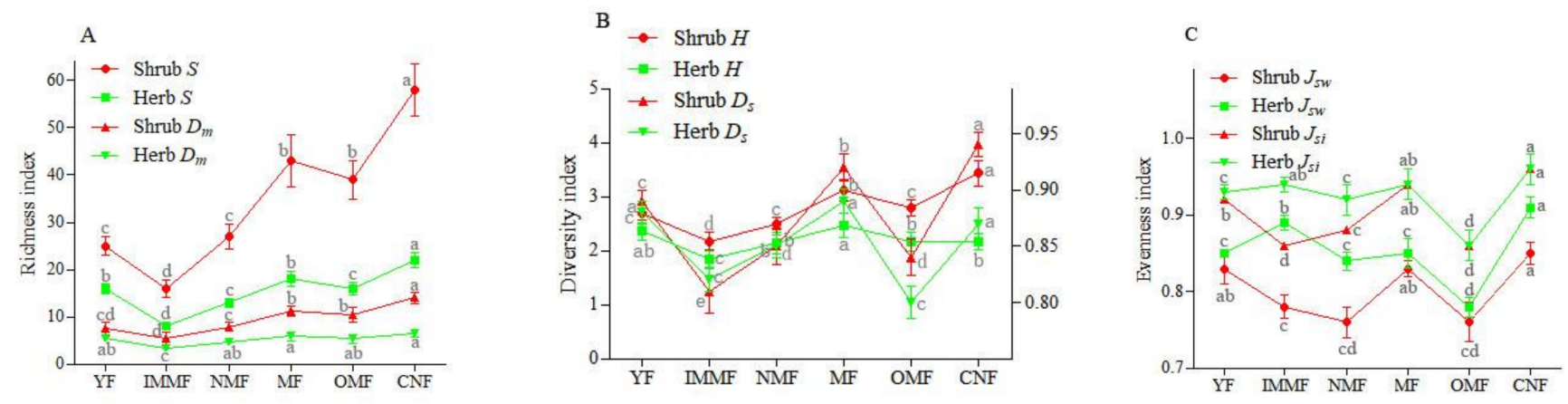

Figure 3. Diversity indices of shrub and grass calculated from plant investigation. (A) Richness index (S) and Margalef index $\left(D_{m}\right),(\mathbf{B})$ Shannon diversity index $(H)$ and Simpson index $\left(D_{s}\right),(\mathbf{C})$ McIntosh evenness index $\left(J_{s i}\right)$ and Shannon evenness index $\left(J_{s w}\right)$. $p$-values within each column were determined by ANOVA. Different lowercase letters between different stand ages in the same soil layer indicate significant differences as determined by Tukey's HSD test $(\alpha=0.05)$.

Above all, in the growth process of Chinese fir plantations, all indexes were high in the mature forest and then declined. As time went by, the undergrowth vegetation species diversities of plantations were significantly different from those of close-to-natural forests. Therefore, we believe that the undergrowth vegetation species were the limiting factors of the development of close-to-natural forestry, especially the undergrowth shrubs (Figure 3).

\subsection{Management Effects on Soil Microbial Diversity}

The Biolog-ECO microplate can comprehensively represent the utilization of 31 carbon sources by soil microbes and can reflect the soil microbial diversities at the metabolic level 
(Figure 4). The AWCD value increased continuously, which means that the comprehensive utilization of 31 kinds of carbon sources by soil microbes increased continuously up to $192 \mathrm{~h}$. Over time, the utilization of various carbon sources by soil microbes in the Chinese fir plantations decreased from YF to NMF, then increased from NMF to CNF. The AWCD of CNF was greater than that of the other plantations, indicating that soil microbial communities in CNF had a greater ability to deal with carbon sources than in other plantations. In addition, the YF presented a declining trend with respect to the NMF and then presented an uptrend with respect to the OMF, but the MF presented little difference compared with the OMF. The AWCD of MF was only about $50 \%$ of that of the CNF. Above all, the result showed that the ability of microbes to deal with carbon sources were different in different aged Chinese fir plantations.

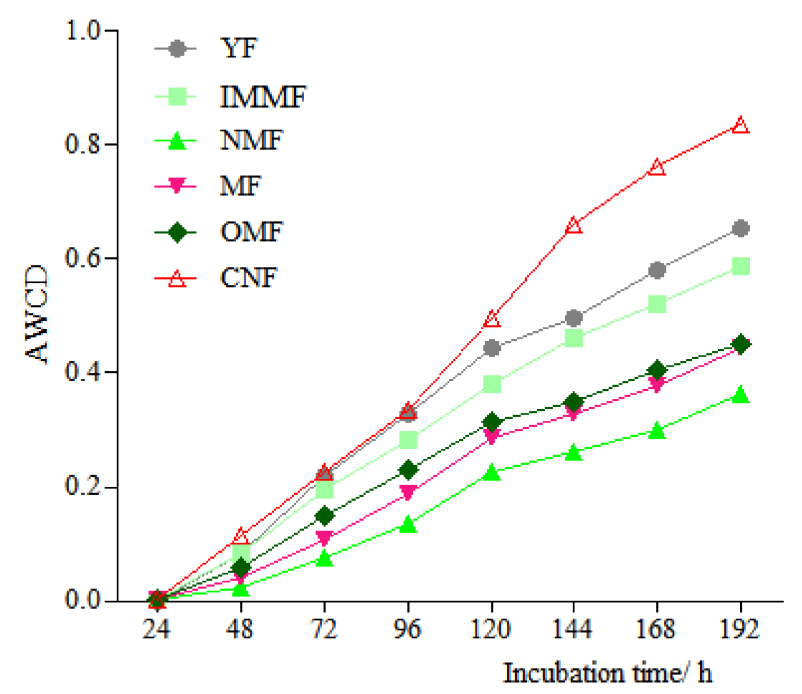

Figure 4. Changes of AWCD of soil microbial communities that utilized carbon sources in 323 different aged stands over time. AWCD is the average well color development.

A total of 408,128 partial 18S rRNA gene sequences were assembled, ranging from 60,419 to 73,198 sequences per sample, of which the CNF accounted for $17.94 \%$, the highest, while the YF (14.80\%) was the lowest. A total of 305,266 partial $16 \mathrm{~S}$ rRNA gene sequences were assembled, ranging from 41,703 to 64,468 sequences per sample, of which the CNF accounted for $21.12 \%$, the MF, $13.73 \%$, and the OMF, $13.66 \%$.

A total of seven fungal phyla and 23 bacterial phyla were detected by comparing the detected sequences with the Silva database. Overall, the diversity indices that received Chinese fir plantations presented a significantly higher soil fungal diversity (Tukey's HSD test, $p<0.05$; Table 4); the Shannon index and Chao1 index were both significantly different (ANOVA; $p<0.05$ ), even though they roughly increased with the forest stand age. ANOVA using the CNF and other plantation as factors showed that the diversity indexes (Shannon index and Chao1 index) for the soil fungal community were significantly different $(p<0.05)$; the diversity of the fungal community in $\mathrm{CNF}$ was significantly higher than that in other plantations (Table 4). Moreover, the soil bacterial diversity indices were also significantly affected by stand age (ANOVA; $p<0.05$ ), but the Shannon index under CNF was not the maximum, and the Chao1 index was not significantly different between the NMF, OMF, and CNF (ANOVA; $p>0.05$, Table 4). 
Table 4. Diversity indices calculated from gene sequence date at the OTU level. Different lowercase letters between different stand ages indicated significant differences as determined by Tukey's HSD test $(\alpha=0.05)$.

\begin{tabular}{ccccc}
\hline \multirow{2}{*}{ Stand Ages } & \multicolumn{2}{c}{ Fungi } & \multicolumn{2}{c}{ Bacteria } \\
\cline { 2 - 5 } & Shannon Index & Chao1 Index & Shannon Index & Chao1 Index \\
\hline YF & $3.46 \pm 0.50 \mathrm{~d}$ & $475.00 \pm 15.29 \mathrm{~d}$ & $5.39 \pm 0.08 \mathrm{~d}$ & $1692.38 \pm 45.03 \mathrm{c}$ \\
$\begin{array}{c}\text { (6 years) } \\
\text { IMMF }\end{array}$ & $3.35 \pm 0.50 \mathrm{~d}$ & $637.26 \pm 20.43 \mathrm{c}$ & $6.14 \pm 0.03 \mathrm{ab}$ & $1915.00 \pm 20.20 \mathrm{~b}$ \\
$\left(\begin{array}{c}15 \text { years }) \\
\text { NMF }\end{array}\right.$ & $3.90 \pm 0.58 \mathrm{c}$ & $475.04 \pm 10.41 \mathrm{~d}$ & $6.00 \pm 0.10 \mathrm{~b}$ & $2031.13 \pm 20.01 \mathrm{a}$ \\
$\left(\begin{array}{c}25 \text { years }) \\
\text { MF }\end{array}\right.$ & $3.88 \pm 0.80 \mathrm{c}$ & $746.37 \pm 15.02 \mathrm{~b}$ & $6.10 \pm 0.09 \mathrm{ab}$ & $1898.96 \pm 45.06 \mathrm{~b}$ \\
$\left(\begin{array}{c}\text { (32 years) } \\
\text { OMF }\end{array}\right.$ & $4.09 \pm 0.70 \mathrm{~b}$ & $643.03 \pm 15.12 \mathrm{c}$ & $6.18 \pm 0.11 \mathrm{a}$ & $2072.43 \pm 30.03 \mathrm{a}$ \\
$(50$ years $)$ & $4.34 \pm 050 \mathrm{a}$ & $1005.51 \pm 50.10 \mathrm{a}$ & $5.85 \pm 0.29 \mathrm{c}$ & $2022.20 \pm 30.33 \mathrm{a}$ \\
CNF & &
\end{tabular}

Analyses of the soil fungal community showed that Ascomycota $(18.60 \%-47.24 \%)$, Basidiomycota (7.22\%-26.92\%), Zygomycota (6.57\%-31.78\%), and Rozellomycota $(0.00 \%-$ $2.50 \%$ ) were the most abundant phyla in all of the treatments (Figure 5A). Among the taxa accounting for more than $1 \%$ of the total number of sequences, unclassified_Fungi had a lower relative abundance in the $\mathrm{CNF}$ treatment while Ascomycota had a higher relative abundance (ANOVA; $p<0.01$ and $p<0.05$ respectively). Analyses of the soil bacterial community showed that Proteobacteria (17.17\%-36.74\%), Acidobacteria (19.00\%-30.62\%), Chlorofiexi (11.95\%$41.50 \%)$, Actinobacteria $(5.41 \%-12.40 \%)$, Plamctomycetes $(2.09 \%-6.11 \%)$, Verrucomicrobia $(2.34 \%-4.39 \%)$, Firmicutes $(1.67 \%-3.38 \%)$, GAL15 $(0.18 \%-6.86 \%)$, and Gemmatimonadetes $(0.33 \%-1.43 \%)$ were the most abundant phyla in all of the treatments (Figure $5 \mathrm{~B}$ ).
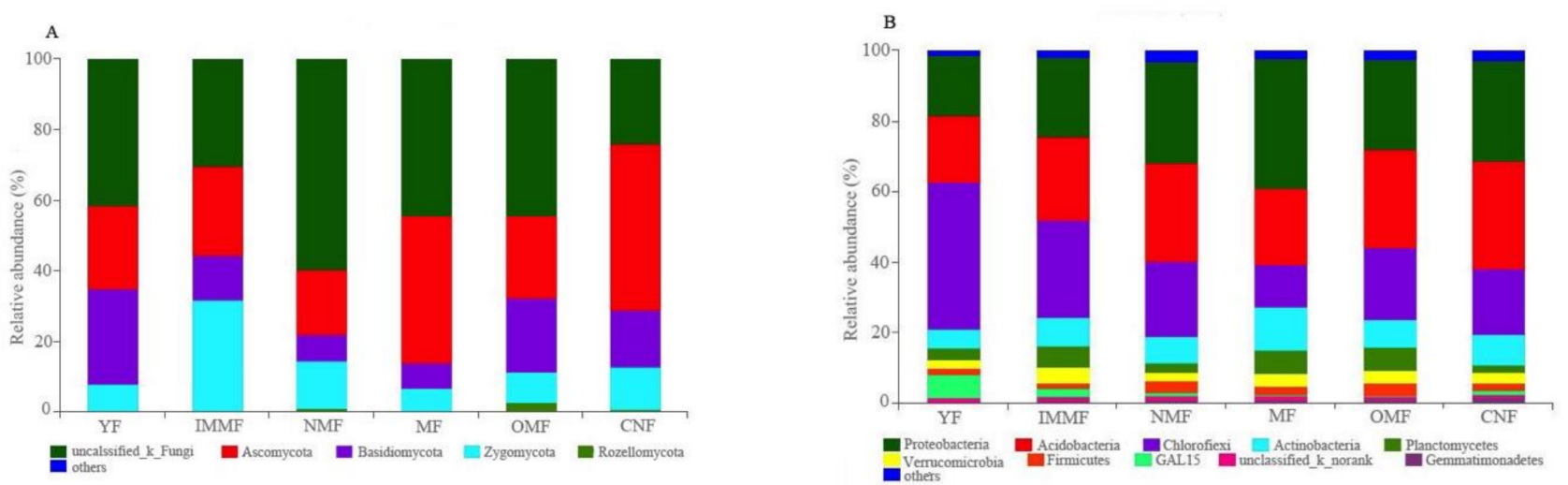

Figure 5. Stacked vertical bars depicting the relative abundance of the taxa present at different stands. Colors in the stacked vertical bars correspond to the phylum level classification of each taxon; taxa accounting for less than $1 \%$ of the total number of sequences are depicted in "others". (A) fungi, (B) bacteria.

\subsection{Correlation Analysis}

The result of the correlation analysis between undergrowth vegetation species diversity and soil properties showed that the richness indexes $\left(S\right.$ and $\left.D_{m}\right)$ and diversity indexes ( $H$ and $D_{s}$ ) of shrubs presented a significant positive correlation with soil $\mathrm{pH}$ and STP $(p<0.01$ or $p<0.05)$, and the richness indexes presented a significant positive correlation with SOM $(p<0.05)$ and STN, STP, STK $(p<0.01)$, while the correlations for herb diversity were lower (Table 4$)$. SAK concentrations had a significantly negative correlation with undergrowth vegetation species diversity $(p<0.01$, Table 4$)$. Of the four soil enzymes, only 
urease was significantly correlated with undergrowth vegetation species diversity $(p<0.01$, Table 5).

Table 5. Correlation analysis between undergrowth vegetation species diversity and soil properties. Soil property dates were the depths of 0-20 cm. PPO = polyphenol oxidase, $\mathrm{UE}=$ urease, $\mathrm{CL}=$ cellulase, $\mathrm{ACP}=$ acid phosphatase, other abbreviations are the same as Figure 1. Asterisks represent the $p$-value: ${ }^{*}=p<0.05,{ }^{* *}=p<0.01$. NS = non-significant.

\begin{tabular}{|c|c|c|c|c|c|c|c|c|c|c|c|c|}
\hline & \multicolumn{6}{|c|}{ Shrub } & \multicolumn{6}{|c|}{ Herb } \\
\hline & $S$ & $D_{m}$ & $\boldsymbol{H}$ & $D_{s}$ & $J_{s w}$ & $J_{s i}$ & $S$ & $D_{m}$ & $H$ & $D_{s}$ & $J_{s w}$ & $J_{s i}$ \\
\hline SBD & NS & NS & NS & NS & NS & NS & NS & NS & NS & NS & NS & NS \\
\hline $\mathrm{pH}$ & $0.885^{* *}$ & $0.853^{* *}$ & $0.614^{* *}$ & $.0649 * *$ & 0.429 & 0.262 & $0.819 * *$ & $0.708^{* *}$ & NS & NS & NS & $0.819^{* *}$ \\
\hline SOM & $0.522 *$ & $0.499 *$ & NS & $0.562 *$ & $0.529 *$ & $0.519 *$ & $0.571 *$ & $0.522 *$ & NS & NS & $0.500 *$ & $0.571^{*}$ \\
\hline STN & $0.661 * *$ & $0.631 * *$ & NS & NS & NS & NS & 0.547 * & NS & NS & NS & NS & $0.547^{*}$ \\
\hline STP & $0.804^{* *}$ & $0.783^{* *}$ & $0.576^{*}$ & $0.551 *$ & NS & $0.512 *$ & $0.707 * *$ & $0.618^{* *}$ & NS & NS & NS & $0.707^{* *}$ \\
\hline STK & $0.614^{* *}$ & $0.614^{* *}$ & NS & NS & NS & NS & NS & NS & NS & NS & NS & NS \\
\hline SAN & NS & NS & NS & NS & NS & NS & NS & NS & NS & NS & NS & NS \\
\hline SAP & NS & NS & NS & NS & NS & NS & NS & NS & NS & NS & NS & NS \\
\hline SAK & $-628 * *$ & $-608^{* *}$ & NS & NS & NS & NS & $-0.526 *$ & NS & -0.487 * & NS & NS & -0.526 * \\
\hline $\mathrm{PPO}$ & NS & NS & NS & NS & NS & NS & NS & NS & NS & NS & NS & NS \\
\hline UE & $0.596^{* *}$ & $0.595^{* *}$ & $0.517^{*}$ & NS & NS & NS & 0.556 * & $0.550^{*}$ & NS & NS & NS & $0.556^{*}$ \\
\hline CL & NS & NS & NS & NS & NS & NS & NS & NS & NS & NS & NS & NS \\
\hline $\mathrm{ACP}$ & NS & NS & NS & NS & NS & NS & NS & NS & NS & NS & NS & NS \\
\hline
\end{tabular}

The results of correlation analysis between soil microbial diversity and soil properties showed that the Shannon index and Chao1 index of fungi had a significant positive correlation with $\mathrm{pH}$, SOM, STN, STP, STK, and urease activities $(p<0.01)$, while the correlations with bacteria were significant only with STK (Table 6).

Table 6. Correlation analysis between soil microbial diversity and soil properties. Soil properties dates were the depths of $0-20 \mathrm{~cm}$. Abbreviations are the same as Table 5. Asterisks represent the $p$-value: ${ }^{*}=p<0.05,{ }^{* *}=p<0.01$. NS $=$ non-significant.

\begin{tabular}{ccccc}
\hline & \multicolumn{2}{c}{ Fungi } & \multicolumn{2}{c}{ Bacteria } \\
\cline { 2 - 5 } & Shannon Index & Chao1 Index & Shannon Index & Chao1 Index \\
\hline SBD & NS & NS & NS & NS \\
pH & $0.846^{* *}$ & $0.676^{* *}$ & 0.079 & $0.496^{*}$ \\
SOM & $0.683^{* *}$ & $0.614^{* *}$ & $-0.504^{*}$ & NS \\
STN & $0.622^{* *}$ & $0.741^{* *}$ & NS & NS \\
STP & $0.725^{* *}$ & $0.869^{* *}$ & NS & NS \\
STK & $0.783^{* *}$ & $0.638^{* *}$ & $0.596^{* *}$ & $0.778^{* *}$ \\
SAN & NS & NS & NS & NS \\
SAP & NS & NS & NS & NS \\
SAK & $-0.740^{* *}$ & NS & NS & $-0.573^{*}$ \\
PPO & $0.618^{* *}$ & NS & NS & $0.532^{*}$ \\
UE & $0.494^{*}$ & $0.691 * *$ & NS & NS \\
CL & NS & NS & NS & NS \\
ACP & $-0.540^{*}$ & NS & NS & $-0.587^{*}$ \\
\hline
\end{tabular}

Correlation analysis between soil microbial diversity and undergrowth vegetation species diversity showed that the Shannon index of fungal communities presented a significant positive correlation with the richness indexes $\left(S\right.$ and $\left.D_{m}\right)$ and diversity indexes $(H)$ of shrubs $(p<0.01$ and $p<0.05$, respectively, Table 6). The Chao1 index of the fungal community presented a significant positive correlation with the richness indexes ( $S$ and $\left.D_{m}\right)$, Shannon index $(H)$, and evenness index $\left(J_{s i}\right)$ of shrubs $(p<0.01, p<0.01$, and $p<0.05$, respectively). In addition, the Shannon index of the fungal community presented a significant positive correlation with the richness indexes $\left(S\right.$ and $\left.D_{m}\right)$ of herbs $(p<0.01)$, and the Chao1 index of the fungal community presented a significantly positive correlation with the richness index $S(p<0.01)$ and $D_{m}(p<0.05)$. Finally, the diversity index of the bacterial 
community was not significantly correlated with undergrowth vegetation species diversity (Table 7).

Table 7. Correlation analysis between soil microbial diversities and undergrowth vegetation species diversities. Asterisks represent the $p$-value: ${ }^{*}=p<0.05,{ }^{* *}=p<0.01$. NS = non-significant.

\begin{tabular}{|c|c|c|c|c|c|}
\hline & & \multicolumn{2}{|c|}{ Fungi } & \multicolumn{2}{|c|}{ Bacteria } \\
\hline & & Shannon Index & Chao1 Index & Shannon Index & Chao1 Index \\
\hline \multirow{6}{*}{ Shrub } & $S$ & $0.904^{* *}$ & $0.829 * *$ & NS & NS \\
\hline & $D_{m}$ & $0.875^{* *}$ & $0.818 * *$ & NS & NS \\
\hline & $H$ & $0.550 *$ & $0.655^{* *}$ & NS & NS \\
\hline & $D_{s}$ & 0.468 & $0.544 *$ & NS & NS \\
\hline & $J_{s w}$ & NS & NS & NS & NS \\
\hline & $J_{s i}$ & NS & $0.525 *$ & NS & NS \\
\hline \multirow{6}{*}{ Herb } & $S$ & $0.753^{* *}$ & 0.649 ** & NS & NS \\
\hline & $D_{m}$ & $0.657^{* *}$ & 0.554 * & NS & NS \\
\hline & $H$ & NS & NS & NS & NS \\
\hline & $D_{s}$ & NS & NS & NS & NS \\
\hline & $J_{s w}$ & NS & NS & NS & NS \\
\hline & $J_{s i}$ & NS & NS & NS & NS \\
\hline
\end{tabular}

\section{Discussion}

\subsection{Influence on Soil Properties and Soil Enzyme Activity}

Soil properties affect soil fertility and are closely related to soil biological activities [34]. Soil physical properties may not be a major obstacle to the natural development of Chinese fir plantations. Although the physical properties of Chinese fir close-to-natural forest were significantly different from those of plantations (Table 2), their values were not significantly higher than those in plantations; these results were similar to the conclusions obtained by other scholars with respect to the difference in soil physical properties between plantations and close-to-natural forests or natural forests. Due to the more complex community structures in the close-to-natural forest, the effect on soil physical properties may not be regular compared to plantations with single tree species. Soil nutrients provide raw materials for plant growth, and the quality of soil nutrients affects plant growth [35-37]. The species and quantities of undergrowth vegetation affected soil properties, which are also the key factors for plant growth [38,39]. In our study, soil properties in different aged Chinese fir plantations were significantly different $[40,41]$. Studies showed that acid soil improvement could improve soil fertility and increase microbial activity [42,43]. Moreover, at the early stand age of Chinese fir plantations, controlled burning has a short-term fertilizer benefit on the soil, and the available nutrient concentrations in the soil are higher than before, which is conducive to the early growth of trees [44]. However, with the growth of Chinese fir, the nutrients were gradually consumed (Figure 1). Studies have indicated that before the growth of Chinese fir to mature forests, Chinese fir is always in the process of nutrient consumption; the concentration of $n, p$, and $\mathrm{K}$ in the soil of 20-year-old Chinese fir generally account for $43.6 \%, 24.3 \%$, and $43.2 \%$ of the respective amounts at planting [45]. In this paper, many soil nutrient indicators including SOM, STN, STP, STK, SAN, and SAP in CNF were higher than in YF (Figure 1), which indicated that with the increase in the age of Chinese fir, the vegetation gradually recovered, the litter layer began to accumulate, and the decomposition of the ground cover allowed the soil nutrients to recover $[44,46,47]$.

As a biocatalyst that can generate specific biochemical reactions in soil, soil enzymes cannot be neglected. Different soil enzymes have different activities in different growth stages of plants. In this paper, urease in the soil presented significantly higher activities after NMF $(p<0.05)$, which showed that the role of urease in Chinese fir plantations increased with the increase in forest age after NMF. The other three enzymes played different roles in different growth processes of Chinese fir $[48,49]$. Studies show that soil enzyme activity is influenced by many factors including soil properties [50], litter decomposition [51], time, 
storage temperature, and substrate age [52], tree species and vegetation disturbance [53,54], and microbial structure [55]. In this paper, the environmental changes caused by different stand ages influenced soil enzyme activities, but we cannot identify the factors that affect the soil enzyme activity if controlled experiments are not performed.

\subsection{Influence on Undergrowth Vegetation Species Diversity and Soil Microbial Diversity}

The undergrowth vegetation species in different ages were different (Table 3), and the shrub and herb diversity indexes were significantly different $(p<0.05$, Figure 3$)$. Due to the single composition and structure of Chinese fir plantations as well as the tall and straight trunks that characterize this species, the difference between individuals was small, resulting in a single forest environment, which limited the diversity of undergrowth vegetation species [56]. Low palatability of a monoculture forest to frugivorous species might limit seed dispersion $[57,58]$. Controlled burning before afforestation could kill the seeds on the surface and belowground over a large area, increasing the distance of the seed sources. Soil preparation is performed prior to plantation establishment [59]. The above conditions influence the development of undergrowth vegetation species. However, with the increase in Chinese fir age, the structure of tree species changes, the activities of frugivorous species increase, and new plants provide seed sources, which increases the richness and diversity of undergrowth vegetation species. Due to the random distribution and low density of Chinese fir plantations as well as the mixed species with different forms of broad-leaved trees, the diversity of the forest environment is conducive to the growth and development of different undergrowth vegetation species [60].

Undergrowth vegetation species diversity affects microbial diversity; microbial diversity provides abundant carbon and nitrogen sources for plants (Wang et al., 2010), and the productivity level and metabolic capacity of microbes also strongly affect the composition and diversity of undergrowth vegetation [61]. The utilization capacity of soil microbes with respect to different carbon sources can reflect the transformation of soil carbon sources and the metabolic diversity of soil microorganisms to a certain extent (Figure 4) [62]. Biolog-ECO results showed that the ability of microbes to deal with carbon sources in Chinese fir plantations decreased with the increase in forest stand age before NMF, but increased after NMF, where those changes indicated that with the increase in forest age, the capacity of microbes to deal with carbon sources increases with the increase in undergrowth vegetation diversity, which makes the ecosystem more stable. The results of high-throughput sequencing showed that there was a significant difference in soil fungal diversities between different aged plantations, while there were no significant differences in bacterial diversity (Table 4), indicating that fungi played a very important role in the development of Chinese fir.

A mutually beneficial symbiotic relationship between undergrowth vegetation and the microbial community is good for biodiversity and ecosystem diversity. Therefore, the development of undergrowth vegetation and the increase in soil microbial diversity may be important biological ways to improve the soil characteristics of forests and restore the productivity of plantations. Undergrowth vegetation plays a unique role in maintaining and improving species diversity, promoting nutrient recycling and effective utilization, improving soil physical and chemical properties, enhancing stand water conservation, preventing soil erosion, optimizing stand structure, and developing more stable communities. The reasonable allocation, scientific, and effective management of undergrowth vegetation can restore the soil characteristics of plantations, and have important theoretical and practical significance for the sustainable management and long-term utilization of plantations $[63,64]$. Soil microbial diversity is closely related to undergrowth vegetation species diversity, and microbes affect vegetation on the ground through various channels. Undergrowth vegetation species diversity can also affect microbial diversity; research indicates that the type and quantity of litter and root exudates have a strong influence on the type and quantity of microbes [65,66], especially the rhizosphere microbial feedback effect [67]. We believe that if we want to realize the close-to-natural development of Chinese 
fir plantations, an effective method is to increase the diversity of undergrowth vegetation, especially shrub species, and then increase the diversity of soil microbes.

\subsection{Correlation Analysis of Limiting Factors}

We analyzed the correlates of undergrowth vegetation species diversity with soil properties (Table 5), soil microbial diversity with soil properties (Table 6), and soil microbial diversity with undergrowth vegetation species diversity (Table 7). The correlation between undergrowth vegetation species diversity and soil properties showed that shrubs and soil properties were more strongly correlated than herbs (Table 5), possibly because shrubs have more species and numbers than herbs, shrubs are more widely distributed than herbs, and shrubs have more roots and litters than herbs. The correlation between soil microbial diversities and soil properties showed that the correlation between fungal diversities and soil properties was higher than for bacteria (Table 6). This result showed that fungi play a greater role in Chinese fir plantations. The correlation between microbial diversity and undergrowth vegetation species diversity showed that there were significant correlations between fungal diversity and undergrowth vegetation species diversity, while there was no correlation between bacterial diversity and undergrowth vegetation species diversity (Table 7). This result showed that undergrowth vegetation species diversity influenced fungal diversity, but bacterial diversity was not influenced by undergrowth vegetation species diversity. In conclusion, we believe that undergrowth vegetation (especially shrubs) affected the soil properties by regulating the fungal community, and shrub diversities and fungal diversities should be emphasized in the development of close-to-natural forestry.

\section{Conclusions}

Soil properties, soil enzyme activities, undergrowth vegetation species diversity, and microbial diversity in close-to-natural Chinese fir forests were significantly different with the age of the plantations. Different forest types influenced soil $\mathrm{pH}$, organic matter, total nitrogen, total phosphorus, total potassium, alkali-hydrolyzed nitrogen, available phosphorus concentrations, urease activities, undergrowth vegetation species, and microbial diversity. Fungal diversity in the close-to-natural forest was significantly higher than in other plantations, in contrast to bacteria. The correlation analysis results showed that the diversity of shrub species with respect to soil properties presented a higher correlation than for herb species, the diversity of fungi with respect to soil properties presented a higher correlation than that observed for bacteria, the diversity of fungi was significantly correlated with the diversity of undergrowth vegetation species diversities, and the correlation between bacteria and undergrowth vegetation species diversities was not significant. We believe that the undergrowth vegetation (especially shrubs) affected the soil properties by regulating the fungal community. In order to realize the close-to-natural development of Chinese fir plantations, an effective method is to increase the diversity of undergrowth vegetation, especially shrub species, and to increase the diversity of fungi. However, we are also insufficient to the changes in microbial communities at different ages with respect to different classifications or functions. In addition, how fungal diversity is affected by shrub diversity has not been studied, and soil enzymes should be further studied individually because of their different functions.

Author Contributions: Conceptualization, L.H., Y.Z. and Q.S.; Methodology, L.H. and Y.Z.; Software, L.H.; Validation, L.H., Y.Z., Z.L., G.S., L.S. and Q.S.; Formal analysis, L.H. and Q.S.; Investigation, L.H., Y.Z., Z.L., G.S., L.S. and Q.S.; Resources, L.H. and Q.S.; Data curation, L.H.; Writing-original draft preparation, L.H. and Y.Z.; Writing-review and editing, L.H., Y.Z., L.S. and Q.S.; Visualization, L.H.; Supervision, Q.S.; Project administration, L.H. and Y.Z.; Funding acquisition, Q.S. All authors have read and agreed to the published version of the manuscript.

Funding: Basic research funding was provided partly by the National Key Research and Development Program of China (No. 2017YFC0505605), and the Fundamental Research Funds for the Central Non-Profit Research Institution of CAF (No. CAFYBB2019SY003). 
Acknowledgments: We would like to thank Qingkang Li (Institute of Botany, the Chinese Academy of Sciences) and Shuhua Lai for their help during soil sampling and plant investigation as well as the technical staff at the experimental farm in Fenyi, who assisted with the field experiments and have managed the field for the many years of the long-term experiment.

Conflicts of Interest: The authors declare no conflict of interest.

\section{References}

1. Douh, C.; Daïnou, K.; Loumeto, J.; Moutsambote, J.M. Soil seed bank characteristics in two central African forest types and implications for forest restoration. For. Ecol. Manag. 2018, 409, 766-776. [CrossRef]

2. Halofsky, J.E.; Andrews-Key, S.A.; Edwards, J.E. Adapting forest management to climate change: The state of science and applications in Canada and the United States. For. Ecol. Manag. 2017, 421, 84-97. [CrossRef]

3. Lefèvre, F.; Koskela, J.; Hubert, J.; Kraigher, H. Dynamic Conservation of Forest Genetic Resources in 33 European Countries. Conserv. Biol. 2013, 27, 373-384. [CrossRef] [PubMed]

4. Shen, L.; Tian, M.R.; Gao, J.X.; Qian, J.P. Spatio-temporal change of sand-fixing function and its driving forces in desertification control ecological function area of Hunshandake, China. J. Appl. Ecol. 2016, 27, 73-82.

5. Zinda, J.A.; Trac, C.J.; Zhai, D. Dual-function forests in the returning farmland to forest program and the flexibility of environmental policy in China. Geoforum 2017, 78, 119-132. [CrossRef]

6. Yu, Z.; Liu, S.R.; Wang, J.X.; Wei, X.H. Natural forests exhibit higher carbon sequestration and lower water consumption than planted forests in China. Glob. Chang. Biol. 2019, 25, 68-77. [CrossRef]

7. Zhou, Q.Q.; Li, F.; Cai, X.A.; Rao, X.Q. Survivorship of plant species from soil seedbank after translocation from subtropical natural forests to plantation forests. For. Ecol. Manag. 2019, 432, 741-747. [CrossRef]

8. Xia, Z.C.; Kong, C.H.; Chen, L.C.; Wang, P.; Wang, S.L. A broadleaf species enhances an autotoxic conifers growth through belowground chemical interactions. Ecology 2016, 97, 2283-2292. [CrossRef]

9. Yang, Y.S.; He, Z.M. On the advantages and disadvantages of the effects of controlled burning on the ecological system of Chinese fir plantation and the countermeasures. J. Nat. Resour. 1997, 2, 153-159. (In Chinese)

10. Xia, L.D.; Xu, Y.X. Researches on soil decline of Chinese fir plantation. World For. Res. 2018, 31, 37-42. (In Chinese)

11. Ma, Q.X. A review for research of productivity decline in Chinese fir plantations after successive plantings. J. Fujian Coll. For. 2001, 21, 380-384. (In Chinese)

12. Chen, L.C.; Wang, S.L.; Chen, C.Y. Degradation mechanism of Chinese fir plantation. Chin. J. Appl. Ecol. 2004, 15, 1953-1957. (In Chinese)

13. Brang, P.; Spathelf, P.; Larsen, J.B.; Bauhus, J.; Boncčìna, A.; Chauvin, C.; Drössler, L.; García-Güemes, C.; Heiri, C.; Kerr, G.; et al. Suitability of close-to-nature silviculture for adapting temperate European forests to climate change. Forestry 2014, 87, 492-503. [CrossRef]

14. Fichtner, A.; Oheimb, G.V.; Härdtle, W.; Wilken, C.; Gutknecht, J.L.M. Effects of anthropogenic disturbances on soil microbial communities in oak forests persist for more than 100 years. Soil Biol. Biochem. 2014, 70, 79-87. [CrossRef]

15. Zhang, Y.P.; Xu, J.L.; Kang, M.Y.; Zhao, C.J. Review on progress in near-natural forestry. Res. Soil Water Conserv 2007, 14, 214-217. (In Chinese)

16. Zheng, C.Z.; Hu, L.Z.; Zheng, W.H.; Yan, L.S.; Jiang, N.C. Current situation and development countermeasure of Chinese Fir plantation construction in forest farm of Kaihua County, Zhejiang Province. East China For. Manag. 2013, 3, 5-9. (In Chinese)

17. Zhou, W.; Chen, L.M. Hu'nan Zhangjiajie national forest peak's Chinese fir plantation landscape reconstruction countermeasures. J. Fujian For. Sci. Technol. 2010, 37, 137-139. (In Chinese)

18. Li, T.T.; Lu, Y.C.; Pang, L.F.; Zhang, X.Q.; Wang, X.; Liu, X.Z.; Jiang, J. Initial Effect of Close-to-Nature Management of Chinese Fir Plantation. Sci. Silva. Sin. 2014, 50, 90-100. (In Chinese)

19. Wang, Q.T. Effectiveness study on the close-to-nature management for mixed forest of Chinese fir. J. Northwest For. Univ. 2014, 29, 95-99. (In Chinese)

20. Shi, J.P. Preliminary effect of close-to-natural management of Chinese fir plantation. J. Green Sci. Technol. 2017, 9, 181-182. (In Chinese)

21. Lin, J.J. Comparative studies on community characteristics of natural forest and plantation of Chinese fir. Mod. Agric. Sci. Technol. 2007, 9, 17-18. (In Chinese)

22. Guo, J.F.; Chen, G.S.; Qian, W.; Yang, S.H.; Yang, Y.S.; Zheng, Q.R. Litter production and nutrient return in two natural forests and a Cunninghamia lanceolata plantation in Wanmulin Nature Reserve. Acta Ecol. Sin. 2006, 26, 4091-4098. (In Chinese)

23. Mao, Y.L.; Yang, Y.S.; Xing, S.H.; Zou, S.Q.; Cui, J.C. A comparison of soil organic carbon of water-stable aggregates between Altingia gracilipes natural Forest and Cunninghamia lanceolata plantation. J. Huaqiao Univ. 2008, 29, 106-110. (In Chinese)

24. Sujii, P.S.; Schwarcz, K.D.; Grando, C.; de Aguiar Silvestre, E.; Mori, G.M.; Brancalion, P.H.S.; Zucchi, M.I. Recovery of genetic diversity levels of a Neotropical tree in Atlantic Forest restoration plantations. Biol. Conserv. 2017, 211, 110-116. [CrossRef]

25. Wu, S.H.; Huang, B.H.; Huang, C.L.; Li, G.; Liao, P.C. The Aboveground Vegetation Type and Underground Soil Property Mediate the Divergence of Soil Microbiomes and the Biological Interactions. Microb. Ecol. 2017, 75, 434-446. [CrossRef]

26. Jing, Z.B.; Cheng, J.M.; Su, J.H.; Bai, Y.; Jin, J.W. Changes in plant community composition and soil properties under 3-decade grazing exclusion in semiarid grassland. Ecol. Eng. 2014, 64, 171-178. [CrossRef] 
27. Institute of Soil Science, Chinese Academy of Sciences. Soil Physical and Chemical Analysis; Shanghai Scientific \& Technical Publishers: Shanghai, China, 1978.

28. Kjeldahl, J. Neuemethode zur bestimmung des stickstos in organischen Körpern. Z. Anal. Chem. 1883, 22, 366-382. [CrossRef]

29. Danilo, S.; Almeida Penn, C.J.; Rosolem, C.A. Assessment of phosphorus availability in soil cultivated with ruzigrass. Geoderma 2018, 312, 64-73.

30. Menšík, L.; Hlisnikovský, L.; Pospíšilová, L.; Kunzová, E. The effect of application of organic manures and mineral fertilizers on the state of soil organic matter and nutrients in the long-term field experiment. J. Soils Sediments 2018, 18, 2813-2822. [CrossRef]

31. Myrvang, M.B.; Hillersoy, M.H.; Heim, M.; Bleken, M.A.; Gjengedal, E. Uptake of macro nutrients, barium, and strontium by vegetation from mineral soils on carbonatite and pyroxenite bedrock at the Lillebukt Alkaline Complex on Stjernøy, Northern Norway. J. Plant Nutr. Soil Sci. 2016, 179, 705-716. [CrossRef]

32. Kieloaho, A.J.; Pihlatie, M.; Carrasco, M.; Kanerva, S.; Parshintsev, J.; Riekkola, M. Stimulation of soil organic nitrogen pool: The effect of plant and soil organic matter degrading enzymes. Soil Biol. Biochem. 2016, 96, 97-106. [CrossRef]

33. Guan, S.Y. Soil Enzymes and Their Research Methods; China Agricultural Press: Beijing, China, 1986. (In Chinese)

34. Ordóñez, I.; López, I.F.; Kemp, P.D.; Descalzi, C.A.; Horn, R.; Zúñiga, F.; Dec, D.; Dörner, J. Effect of pasture improvement managements on physical properties and water content dynamics of a volcanic ash soil in southern Chile. Soil Tillage Res. 2018, 178, 55-64. [CrossRef]

35. Potthast, K.; Hamer, U.; Makeschin, F. In an Ecuadorian pasture soil the growth of Setaria sphacelata, but not of soil microorganisms, is co-limited by N and P. Appl. Soil Ecol. 2012, 62, 103-114. [CrossRef]

36. Hungate, B.A.; Hart, S.C.; Selmants, P.C.; Boyle, S.I.; Gehring, C.A. Soil responses to management, increased precipitation, and added nitrogen in ponderosa pine forests. Ecol. Appl. 2007, 17, 1352-1365. [CrossRef]

37. Fang, X.M.; Zhang, X.L.; Chen, F.S.; Zong, Y.Y.; Bu, W.H. Phosphorus addition alters the response of soil organic carbon decomposition to nitrogen deposition in a subtropical forest. Soil Biol. Biochem. 2019, 133, 119-128. [CrossRef]

38. Lin, J.H. Comparative Study on Soil Moisture and Physical Properties of Different Forest Types; South China Agriculture University: Guangzhou, China, 2016. (In Chinese)

39. Wang, X.Y.; Wang, Q.C. Effects of the close-to-natural cultivation of Larix olgensis and Fraxinus mandshurica on the soil physiochemical properties. Sci. Silva. Sin. 2008, 44, 21-27. (In Chinese)

40. Sun, Q.W.; Yang, C.D.; Jiao, R.Z. The changes of soil properties of the successive Chinese fir plantation in Dagang mountain of Jiangxi Provience. Sci. Silva. Sin. 2003, 39, 1-5. (In Chinese)

41. Sheng, W.T.; Yang, C.D.; Fan, S.H. Variation of soil properties of Chinese Fir plantation. Fore. Res. 2003, 16, 377-385. (In Chinese)

42. Raboin, L.M.; Razafimahafaly, A.H.D.; Rabenjarisoa, M.B.; Rabary, B.; Dusserre, J.; Becquer, T. Improving the fertility of tropical acid soils: Liming versus biochar application? A long term comparison in the highlands of Madagascar. Field Crop. Res. 2016, 199, 99-108. [CrossRef]

43. Pandit, N.R.; Mulder, J.; Hale, S.; Martinsen, V.; Schmidt, H.P.; Cornelissen, G. Biochar improves maize growth by alleviation of nutrient stress in a moderately acidic low-input Nepalese soil. Sci. Total Environ. 2018, 625, 1380-1389. [CrossRef]

44. Lin, W.L. Effects of controlled burning on species diversity and soil fertility. J. For. Eng. 2002, 16, 37-38. (In Chinese)

45. Xu, H.C. A comparative evaluation of the man-made forest and natural forest. World For. Res. 1991, 3, 50-56. (In Chinese)

46. Schnecker, J.; Borken, W.; Schindlbacher, A.; Wanek, W. Little effects on soil organic matter chemistry of density fractions after seven years of forest soil warming. Soil Biol. Biochem. 2016, 103, 300-307. [CrossRef] [PubMed]

47. He, B.; Yuan, X.; Liu, Y.H.; Zhai, X.C.; Mo, Y.F.; Huang, X.M. Studies on the change of soil nutrient before and after controlled burning all cutting woodland of Pinus massoniana plantation. Genom Appl. Biol. 2002, 21, 216-218. (In Chinese)

48. Wang, S.Q.; Li, T.X.; Zheng, Z.C. Effects of tea plantation age on soil aggregate-associated C-and N-cycling enzyme activities in the hilly areas of Western Sichuan, China. CATENA 2018, 171, 145-153. [CrossRef]

49. Tischer, A.; Blagodatskaya, E.; Hamer, U. Microbial community structure and resource availability drive the catalytic efficiency of soil enzymes under land-use change conditions. Soil Biol. Biochem. 2015, 89, 226-237. [CrossRef]

50. Liu, G.M.; Zhang, X.C.; Wang, X.P.; Shao, H.B.; Yang, J.S.; Wang, X.P. Soil enzymes as indicators of saline soil fertility under various soil amendments. Agric. Ecosyst. Environ. 2017, 237, 274-279.

51. Dilly, O.; Munch, J.C.; Pfeiffer, E.M. Enzyme activities and litter decomposition in agricultural soils in northern, central, and southern Germany. J. Plant Nutr. Soil Sci. 2007, 170, 197-204. [CrossRef]

52. Deforest, J.L. The influence of time, storage temperature, and substrate age on potential soil enzyme activity in acidic forest soils using MUB-linked substrates and L-DOPA. Soil Biol. Biochem. 2009, 41, 1180-1186. [CrossRef]

53. Caldwell, B.A.; Griffiths, R.P.; Sollins, P. Soil enzyme response to vegetation disturbance in two lowland Costa Rican soils. Soil Biol. Biochem. 1999, 31, 1603-1608. [CrossRef]

54. Weand, M.P.; Arthur, M.A.; Lovett, G.M.; McCulley, R.L.; Weathers, K.C. Effects of tree species and N additions on forest floor microbial communities and extracellular enzyme activities. Soil Biol. Biochem. 2010, 42, 2161-2173. [CrossRef]

55. Li, J.; Zhou, X.; Yan, J.X.; Li, H.J.; He, J.Z. Effects of regenerating vegetation on soil enzyme activity and microbial structure in reclaimed soils on a surface coal mine site. Appl. Soil Ecol. 2015, 87, 56-62. [CrossRef]

56. Stéphane, B.; Frédéric, G.; Balandier, P. Influence of tree species on understory vegetation diversity and mechanisms involved-A critical review for temperate and boreal forests. For. Ecol. Manag. 2008, 254, 1-15. 
57. Adler, G.H. Tropical tree diversity, forest structure and the demography of a frugivorous rodent, the spiny rat (Proechimys semispinosus). J. Zool. 2015, 250, 57-74. [CrossRef]

58. Vleut, I.; Galindo-González, J.; De Boer, W.F.; Levy-Tacher, S.I.; Vazquez, L.B. Niche Differentiation and its Relationship with Food Abundance and Vegetation Complexity in Four Frugivorous Bat Species in Southern Mexico. Biotropica 2015, 47, 606-615. [CrossRef]

59. Pigan, I. The effect of soil preparation on pine seedling performance in plantations established in moist forest habitats. Sylwan 2009, 153, 745-757.

60. Liang, J.; Sun, Z.Q.; Qiao, J.; Zhang, X.H. Relation between natural forest stability and pest disturbance: To control and to be controlled. Acta Ecol. Sin. 2010, 9, 2454-2464. (In Chinese)

61. Zechmeister-Boltenstern, S.; Keiblinger, K.M.; Mooshammer, M.; Peñuelas, J.; Richter, A. The application of ecological stoichiometry to plant-microbial-soil organic matter transformations. Ecol. Monogr. 2016, 85, 133-155. [CrossRef]

62. Lu, S.B.; Guo, X.M.; Rui, Y.C.; Zhou, X.Q.; Chen, C.R.; Xu, Z.H.; Niu, D.K. Utilization of carbon sources by the soil microbial community of different forest type in subtropical Australia. Acta Ecol. Sin. 2012, 32, 2819-2826. (In Chinese)

63. Silva, G.L.; Lima, H.V.; Campanha, M.M.; Gilkes, R.J.; Oliveira, T.S. Soil physical quality of Luvisols under agroforestry, natural vegetation and conventional crop management systems in the Brazilian semi-arid region. Geoderma 2011, 167, 61-70. [CrossRef]

64. Wang, C.T.; Wang, G.X.; Liu, W.; Wang, W.; Hu, L.; Ma, L. Effects of establishing an artificial grassland on vegetation characteristics and soil quality in a degraded meadow. Isr. J. Ecol. Evol. 2013, 59, 141-153. [CrossRef]

65. Chen, T.; Xi, M.; Kong, F.L.; Li, Y.; Pang, L.H. A review on litter decomposition and influence factors. Chin. J. Ecol. 2016, 35, 1927-1935. (In Chinese)

66. Hackl, E.; Pfeffer, M.; Donat, C.; Bachmann, G.; Zechmeister-Boltenstern, S. Composition of the microbial communities in the mineral soil under different types of natural forest. Soil Biol. Biochem. 2005, 37, 661-671. [CrossRef]

67. Jangid, K.; Williams, M.A.; Franzluebbers, A.J.; Schmidt, T.M.; Coleman, D.C.; Whitman, W.B. Land-use history has a stronger impact on soil microbial community composition than aboveground vegetation and soil properties. Soil Biol. Biochem. 2011, 43, 2184-2193. [CrossRef] 